\title{
Bilinçli Farkındalık ve Psikolojik Sağlamlık Arasındaki İlişkide Temel Empati Becerilerinin Aracı Rol Etkisinin İncelenmesi
}

\author{
Dr. Öğretim Üyesi Nesrullah Okan ${ }^{1 *}$ \\ Mücahit Yılmaztürk ${ }^{2}$ \\ Betül Kürüm ${ }^{3}$
}

Gelis tarihi: 10.05 .2020

Kabul tarihi: 18.06 .2020

\section{Atıf bilgisi:}

IBAD Sosyal Bilimler Dergisi

Sayı: $8 \quad$ Sayfa: $319-335$

Yıl: 2020 Dönem: Güz

This article was checked by iThenticate. Similarity Index 16\%

Bu makalede araştırma ve yayın etiğine uyulmuştur.

${ }^{1}$ Fırat Üniversitesi, Turkiye, nesrokan@gmail.com

ORCID ID 0000-0002-9496-6417

${ }^{2}$ Marmara Üniversitesi, Türkiye, mchtylmztrk@gmail.com,

ORCID ID 0000-0001-9366-7290

${ }^{3}$ Marmara Üniversitesi, Türkiye, kurumbtl@gmail.com

ORCID ID0000-0002-8362-5801

* Sorumlu yazar
ÖZ

$\mathrm{Bu}$ araştırmanın amacı üniversite öğrencilerinde bilinçli farkındalık ve psikolojik sağlamlık arasındaki ilișkide bilișsel empati ve duygusal empati değișkenlerinin aracı rolünün yapısal eşitlik modeli çerçevesinde incelenmesidir. Bilinçli farkındalık, psikolojik sağlamlık ve empati değişkenlerinin çeşitli demografik değişkenler açısından incelenmesi de amaçlanmıştır. Araştırmanın evrenini Marmara Üniversitesi'nde 2018-2019 eğitim-öğretim yılında aktif öğrenim gören toplam 77134 öğrenci oluşturmaktadır. Araştırmanın örneklemini, seçkisiz örnekleme yöntemi ile seçilen Marmara Üniversitesi’nde aktif öğrenim gören 360 öğrenci olușturmaktadır. Araştırmada kișisel bilgi formu, Bilinçli Farkındalık Ölçeği, Psikolojik Sağlamlık Ölçeği ve Temel Empati Ölçeği kullanılarak veriler toplanmıştır. Araştırmanın amaçlarını test etmek üzere verilerin analizinde bağımsız gruplar t testi, ANOVA (tek yönlü varyans analizi), pearson momentler çarpımı korelasyonu ve yol analizi kullanılmıştır. Yapılan yol analizi sonucunda, bilinçli farkındalık ve psikolojik sağlamlık arasındaki ilişkide bilişsel ve duygusal empati değişkenlerinin kısmi aracı rolü etkisi olduğu görülmüştür. Araştırma literatür 1şı̆̆ında tartışılmış ve araștırmaya son hali verilmiştir.

Anahtar Kelimeler: Psikolojik sağlamlık, bilinçli farkındalık, bilişsel empati, duygusal empati 


\title{
Investigation of the Mediator Role Effect of Cognitive Empathy and Emotional Empathy
} Variables in the Relationship between Mindfulness and Resilience

\author{
Dr. Öğretim Üyesi Nesrullah Okan ${ }^{1 *}$ \\ Mücahit Yılmaztürk ${ }^{2}$ \\ Betül Kürüm ${ }^{3}$
}

First received: 10.05 .2020

Accepted: 18.06 .2020

\section{Citation:}

IBAD Journal of Social Sciences

Issue: 8

Pages: $319-335$

Year: 2020

Session: Fall

This article was checked by iThenticate. Similarity Index 16\%

\footnotetext{
${ }^{1}$ Firat University, Turkey, nesrokan@gmail.com

ORCID ID 0000-0002-9496-6417

${ }_{2}^{2}$ Marmara University, Turkey, mchtylmztrk@gmail.com, ORCID ID 0000-0001-9366-7290

${ }^{3}$ Marmara University, Turkey, kurumbtl@gmail.com

ORCID ID 0000-0002-8362-5801
}

* Corresponding Author

\begin{abstract}
The aim of this study is to examine the mediating role of cognitive empathy and emotional empathy variables in the relationship between mindfulness and resilience among university students within the framework of Structural Equation Model. The population of the study consists of 77134 students who are actively studying in the 2018-2019 academic year at Marmara University. The sample of the study consists of 360 students who are actively studying at Marmara University, which is selected by random sampling method. Data were collected by using personal information form, Mindfullness Scale, Resilience Scale and Basic Empathy Scale. Independent groups t test, ANOVA (one way analysis of variance), pearson product moment correlation and path analysis were used to analyze the data. As a result of the path analysis, it was seen that cognitive and emotional empathy variables had a partial mediating role in the relationship between mindfullness and resilience. The research was discussed in the light of the literature and the research was finalized.
\end{abstract}

Key Words: Resilience, mindfullness, cognitive empathy, emotional empathy. 


\section{GíRIS}

Bireyin psikolojik olarak sağlam olması hiç şüphesiz yaşam kalitesi noktasında oldukça önemli bir husustur. Zira psikolojik olarak sağlam olan bireylerin, gerek aldıkları kararlar gerekse toplumsal yaşamdaki ilişki becerileri daha sağlıklı bir zeminde şekillenmektedir. (Öz, Bahadır-Yılmaz, 2009). Aynı şekilde psikolojik sağlamlığı yüksek bireylerin bilinçli farkındalıklarının da yüksek olması beklenen bir durumdur. Bununla birlikte temel empati becerilerinin de psikolojik sağlamlıkla doğrudan ilişkili olduğu düşünülmektedir. Bu bağlamda bilinçli farkındalık, temel empati ve psikolojik sağlamlık değişkenlerinin birbirleriyle olan ilişkilerinin ele alınması ve incelenmesi önem arz etmektedir.

\section{Bilinçli Farkındalık}

Bilinçli farkındalık kavramı son dönemlerde psikolojide oldukça önem kazanan bir kavram haline gelmiştir. Bunun temel nedenlerinden birisi, bilinçli farkındalığın psikolojik sorunlarda önemli bir etkiye sahip olduğu görüşünün gittikçe hâkim olmasıdır. Bilinçli farkındalık kavramının kökeni esasen doğu meditasyonuna dayanmaktadır (Kabat-Zinn, 1990). Literatürde bilinçli farkındalık kavramı incelendiğinde teorik bir altyapıya sahip olmakla beraber bireylerin yaşantılarına dair dingin bir zihin arayışının pratiği olup aynı zamanda içsel bir süreç şeklinde de karşımıza çıktığı görülmektedir (Germer, Siegel ve Fulton, 2005).

Tarihsel açıdan incelendiğinde budizm pratiği olarak karşımıza çıkan bilinçli farkındalık, günümüzde batı toplumlarında da merak uyandıran bir kavram haline gelmiştir (Özyeşil, 2011b). Bununla birlikte egzistansiyalizm, hümanist (insancıl) görüş, fenomenolojik yaklaşım (görüngü bilim) vb. muhtelif felsefik ve psikolojik temellerle de yapısal anlamda benzerlik göstermektedir (Brown ve ark., 2007). Bilinçli bir hayat sürdürmenin temel dinamiği bireyin kendisini olduğu gibi kabul etmesi ve çevresine de kabul ettiği şekliyle yansıtmasıdır. Bu süreç, bireyin kendisini gözlemleyerek davranışlarına odaklandığı metabilişsel bir süreçtir.

Bilinçli farkındalık kavramını etimolojik olarak incelediğimizde Pali dilindeki "sati” sözcügünden türemiş olup manasının ise "hatırlamak" olduğu görülmektedir (Tuncer, 2017) . Sati kelimesi ise 1921 yılında bilinçli farkındalık şeklinde tercüme edilmiştir (Çelikler, 2017) TDK'ya (2019) göre bilinç, insanın kendisini ve çevresini bilme yetisi olarak tarif edilmiştir. Neff (2003) bilinçli farkındalığı, kişide meydana gelen olumsuz durumlardan kaçınmak yerine bu durumları yargılamadan anlamaya ve yorumlamaya çalışmak olarak tanımlamıştır. $\mathrm{Bu}$ durum, kişinin karşılaştığı olumsuz duygu ve düşüncelerinin farkına varmasına yardımcı olmaktadır. Kişinin kendisi ile ilgili sağlıklı düşünmeye başlaması, ona rahatsızlık veren durumlar yerine soruna odaklanmasını kolaylaştırmaktadır. Bilinçli farkındalık (mindfulness) geçmiş tecrübeleri hatırlamayı içinde bulundurmakla birlikte bu yaşantılara saplanıp andan uzaklaşmak anlamına gelmez (Özyeşil ve ark., 2011). Bazı insanlar günlük yaşantılarını tekdüze bir şekilde devam ettirirler. Bu hayat tarzı, bireylerin farkındalığını düşürerek yaşadıklarıyla ilgili kişide akılda kalıcı bir etki bırakmaz. Tıpkı bireyin merdivenden inerken ya da çıkarken üstüne kafa yormaması ve o ana odaklanmaması gibidir. $\mathrm{Bu}$ durum "dikkatsizlik (mindlesness)" şeklinde tanımlanmaktadır (Arslan, 2018).

Kabat ve Zinn (1994) bilinçli farkındalığı, kişinin kendisini yargılamadan, dikkatini toparlayabilmesi ve bulunduğu ana yoğunlaştırabilmesi şeklinde ifade etmektedirler. Bu yoğunlaşma sürecinde, birey kendisine yönelik olumsuz eleştiri ve yargılama yerine, kendini anlama ve kabullenme safhasina geçebilmektedir. Bu durum bireyin kendisine yönelik olan şefkatini artırmaktadır (Deniz ve ark., 2008). Bunun neticesinde kişinin psikolojik olarak daha sağlam bir hale gelmesi beklenmektedir.

Germer ve ark. (2005) göre ise bilinçli farkındalık, sosyal yaşantılarımızda bütünüyle agâh olma yolunda bir vesiledir. Bilinçli farkındalık uyanık olmaktır fakat birçok insan yaşadıkları durum karşısında zihinsel süreçlerini bilinçli farkındalıkla yönetemez. Bu gibi durumlarda birey yaşadığı olaylara karşı anlık olarak ilgisini yitirmektedir. Bilinçlilik durumu ise bireyin duygusal ve bilişsel manada denge durumunu korumasıdır. Farkındalığı üst düzeyde olan bireyler tecrübelerini doğru-yanlış veya olumlu-olumsuz olarak ayırmaz. Yaşadıklarını değiştirmeden, çarpıtmadan değerlendirirler (Akın ve ark., 2007). Germer (2009)'e göre yaşadığımız olaylarla benliğimizi aşırı özdeşleştirmemiz, bilinçli farkındalık düzeyimizi düşürür. Bunun yerine bilinçli farkındalık becerisi, olumsuz yaşantılar karşısında duygularımızı olduğu 
gibi yani ne daha eksik ne daha fazla hissetmemiz konusunda bize destek olur (Özyeşil, 2011b). Bu bağlamda bilinçli farkındalık, bireyin psikolojik yönüyle kendisini daha sağlam hissetmesi noktasında oldukça önemlidir. Zira kişi ancak sorunlarının farkına varırsa, sorunlarla daha etkin mücadele yetisi kazanabilir.

\section{Psikolojik Sağlamlık}

Psikolojik sağlamlığı yüksek olan bireyler, çok yönlü bakış açısına sahip olduklarından dolayı, olaylar ve durumlardan daha az etkilenmekte ve bunların üstesinden daha kolay gelmektedirler. Böylesi bir durum bireylerin gerek iletişim becerilerine gerek farkındalık düzeylerine ve gerekse de başa çıkma becerilerine olumlu katkıda bulunmaktadır.

Psikolojik sağlamlık kavramı klasik psikolojinin sorun odaklı anlayışından, 'bireyin sağliklı olduğunu, pozitif özelliklerinin geliştirilmesi gerektiğini’ dile getiren pozitif psikoloji anlayışına geçiş ile gündeme gelmiştir.

Psikolojik sağlamlık kavramı ile alakalı yapılan çalışmaların önem kazanmasının başlıca sebeplerinden biri de insanların zorlu hayat koşullarına rağmen karşılaşılan güçlüklerle başa çıkabilme becerilerinin ön plana çıkmasıdır. Psikolojik sağlamlık kavramı ile ilgili olarak yapılan ilk çalışmalarda şunlar merak edilmiştir: 1) Neden bazı bireyler olumsuz yaşantılarla karşılaştığında diğerlerine nazaran olumlu tepkiler verip daha dayanıklı bir tutum sergilemektedir? 2) Bu özelliklere sahip olan bireylerin ayırt edici nitelikleri nelerdir? (National Institute of Mental Health, 1995, s. 26). Alanyazın incelendiğinde psikolojik sağlamlık kavramının köken itibari ile 2. Dünya Savaşından sonraki döneme yani 1950'li yıllara dayanmakta olup tıp alanında ortaya çıktığ görülmektedir (Ezer, 2017). Latince "resilire" sözcügünden meydana gelen psikolojik sağlamlık anlam itibariyle tıpkı lastik gibi esneyebilmesi ve bırakıldığında rahatça önceki formunu alabilmesi, kendini toparlayabilmesi şeklinde açıklanmıştır (Masten \& Gewirtz, 2006).

Psikolojik sağlamlık, tarihsel süreç içerisinde incelendiğinde kavramın birden fazla tarifi olduğu görülmektedir. Bunun temel sebeplerinden biri de sosyal bilimlerde kullanılan terim, tanım ve teorilerin bir taraftan ortaya çıkaran ve işlevsel hale getiren bilim insanının tecrübelerinden etkilenirken diğer taraftan da benimsediği felsefi alt yapı ve mensubu olduğu kültürün fikri yapısını da muhtevasında barındırmasıdır (Sezgin, O., \& Sezgin, A. S., 2011). Psikolojik sağlamlık, olumsuz yaşantılar veya travmatik olaylarla başa çıkabilme, sebat gösterebilme, kararlı davranabilme, içinde bulunduğu koşullara adapte olabilme ve bu şekilde hayatını idame ettirebilmektir (Garmezy, 1991; Luthar \& ark., 2000; Masten, Best, \& Garmezy, 1990). Wagnild ve Young (1993) ise psikolojik sağlamlığı bireyin hayatında karşılaştı̆̆ güçlüklerle sağlıklı bir biçimde başa çıkabilme kabiliyeti olarak nitelendirmektedir. Bir başka tanımda ferdin yaşadığı güç ve başa çıkması zor durumları dikkate almadan kaygılı durumlarla baş edebilme becerisi şeklinde değerlendirilmektedir (Brooks ve Goldstein, 2003).

Psikolojik sağlamlık ile ilgili ortaya konulan önceki araştırmalarda kavramın, kişinin kalıtsal olarak ortaya çıkan mizaci yönünü belirtmesine karşın günümüzde değişken ve dinamik bir yapıya sahip olduğu görüşü ağırlık kazanmıştır (Luthar, Cicchetti ve Becker, 2000). Psikolojik sağlamlığın farklı bakış açıları çerçevesinde çeşitli tanımları incelendiğinde tanımlar arasında bazı benzerlikler olduğu görülmüştür. $\mathrm{Bu}$ benzer noktalar etkin ve devinimsel bir yapıya sahip olması, güçlükler karşısında pozitif adaptasyon süreçlerini içermesi, kişinin başa çıkma becerilerini geliştirmesi ve zorlu hayat şartlarının beraberinde getirdiği risk faktörleri ve ortaya çıkardığı negatif tesirleri minimize eden koruyucu (önleyici) faktörler şeklinde siralanabilir (Garmezy, Masten ve Tellege1111n, 1984; Luthar ve Cicchetti, 2000; Luthar ve Cichetti ve Becker, 2000; Masten ve Reed, 2002).

Psikolojik sağlamlık, kişinin ruh sağlığını koruyucu bir tampon rolündedir. Zorlayıcı veya travmatik bir durumun ortaya çıkma ihtimali göz önünde bulundurulduğunda psikolojik sağlamlı̆̆ın sosyal uyum, bilişsel becerilerin gelişimi, duygusal farkındalık kazandırma, etkili iletişim kurabilme vb. birçok olumlu niteliği beraberinde getirdiği görülmektedir (Baş ve Yurdabakan, İ., 2017). 
Psikolojik sağlamlığı yüksek olan bireylerin ortak özellikleri bulunmaktadır. Yapılan bir çalışmada Haynes (2005) psikolojik sağlamlığı üst seviyede olan kişileri niteliksel olarak üç farklı açıdan incelenmiştir:

Sosyal anlamda; Atılganlık becerisi, sosyal ilişkilerde bulunabilme ve sürdürebilme, sosyal destek kaynağına sahip olmasına karşın destek talebinde bulunmama, kişilerarası iletişim becerisi.

Duygusal anlamda; Özgüven sahibi, kendiyle barışık, adaptasyon kabiliyetine sahip, zorlayıcı koşullar altında yılgınlık göstermeme, yaşadıkları olaylar karşısında gösterilen duygusal tepkilerin uyumlu olması.

Bilişsel anlamda; Yapabileceğine olan inanç, karşılaştı̆̆ı sorunlarla ussal yaklaşabilme, zaman yönetimi, zihinsel potansiyelini üst seviyede kullanabilme, mensubu olduğu topluluğa yararlı olacak faaliyetlerde aktif rol alma, iç denetim odaklı olabilme.

Şekil 1. Psikolojik Sağlamlı̆̆ Yüksek Birey Özellikleri (Haynes, 2005)

\section{Temel Empati}

Psikolojik sağlamlığın ilgili olduğu diğer bir kavram da empati kavramıdır. Empati ve psikolojik sağlamlık kavramlarının birlikte ele alınıp incelenmesi temel bazı noktaları görme açısından oldukça önemli bir husustur.

Empati kişinin çevresiyle olan etkileşim ve uyumunu artıran , kişilerarası iletişimi destekleyen sosyal bir beceridir. Empati, Antik Yunan dilindeki "empatheia" sözcügünden türemiş olup anlam itibariyle bireyin olaylar karşısında eylemde bulunmasını sağlayan bir durum olarak bilinmektedir (Ataşalar, 1996). Empati kavramından ilk kez Aristo'nun yazdığı Rhetoric isimli yapıtında bahsedilmiştir (Sharma, 1992). Türk kültüründe ise empati kelimesinin eş anlamlısı olarak 'diğergamlık' kelimesi kullanılmıştır (Akduman ve ark., 2018). Literatürde bu șekilde ifade edilmekle birlikte Türk kültüründe empati kavramının karşılı̆̆ı hemhal olmaktır diyebiliriz. Kelimenin Almanca tercümesi ise bilim adamı Theodor Lipps tarafından 1897 senesinde "einfühlung" olarak yapılmıştır (Barrett-Lennard 1981; SchützenbergerAncelin 1995). Barret-Lennard (1981) göre kavramsal olarak einfühlung, herhangi bir kişi veya nesneyi tanımaya çalışırken bireyin kendisini karşısındaki nesne veya kişinin yerine koyması ve özdeşim (identification) halinde olmas1 anlamlarına gelmektedir. Bryant and Clark (2006) empatinin bazı zamanlar sempati ile karıştırıldığını ancak ikisinin birbirlerinden farklı kavramlar olduğunu dile getirmişlerdir. Dökmen (2005) empati ve sempati kavramlarını açıklarken; empatiyi diğerinin duygularını anlama olarak açıklarken, sempatiyi ise diğerinin duygularıyla özdeşim kurabilme olarak ifade etmiştir.

Alanyazın incelendiğinde empatinin başkalarının duygularının farkına varma, idrak etme ve onlara bunu aktarabilme becerisi şeklinde tanımlandığı görülmektedir (McWhirter ve Voltan-Acar, 1985). Bir başka tanımda ise iletişim halinde olunan bireyin bilişsel ve duyuşsal tepkilerini net bir şekilde anlamlandırmak, içselleştirmek ve bunu karşı tarafa aktarma yeteneği olarak tarif edilmiştir (Rogers, 1983). Empati, çeşitli görüşlere saygılı olmak, bu görüşlerle uyumlu tavırlar sergilemek ve olayları karşısındaki kişinin persfektifinden ele alabilmektir (Akduman ve ark., 2018). 
Tarihsel açıdan bakıldığında bazı bilim insanlarının empatiyi tanımlarken ilk olarak duygusal (emotional) faktörlere vurgu yaptığı görülürken daha sonra ise bilişsel (cognitive) faktörleri ön plana çıkardığı görülmektedir. Yapılan son çalışmalarda ise empati, indirgemeci bir yaklaşımla yalnız duygusal veya yalnız bilişsel faktörlerle açıklanmak yerine Davis (1980) ve Hoffman (1987) gibi bilim insanları tarafından birçok unsurun etki ettiği çok boyutlu bir yapı olarak ele alınmıştır.

\section{Bilişsel Empati}

Empatinin bilişsel boyutu, bireyin iletişim halinde olduğu nesne veya kişinin herhangi bir olay sonucunda yaşadığ $\breve{1}_{1}$ duyguları idrak etmesi ve bu duyguları anlamlandırması olarak tarif edilmiştir (Staub, 1987). Bireyin, diğerleri ile empati kurması noktasında öncelikli şartlardan biri bilişsel anlamda kendi varlığı ile ötekilerin varlığının ayrımının farkına varması ve karşısındakinin içinde bulunduğu duygulanım sürecini sağlıklı bir şekilde değerlendirmesidir (Hoffman, 1984). Hogan'a (1969) göre empati, iletişim halinde olunan bireyin ruhsal durumunu algılamadır.

Tarihsel süreç içerisinde empati kavramı incelendiğinde bilişsel faktörlere yapılan vurgunun yanında duygusal faktörlerin de önemine değinen bilim insanları, gelişimsel süreç içerisinde bireylerin duyguları zihinsel boyutta değerlendirerek duygusal anlamda davranışlarına yansıttığını gözlemlemişlerdir (Tompson ve Gullone, 2003).

\section{Duygusal Empati}

Wiseman'a (1996) göre empati ‘diğer bireyin yaşadıklarını hayal ederek, duygularını hissederek onu bütünüyle keşfetme gücü' şeklinde tarif edilmiştir. Empatinin duygusal yönü, olayı tecrübe eden birey ile duygusal manada hemhal olmak ve bu durumu karşısındakine yansıtma sürecidir (Staub, 1987). Empati kurabilme yeteneği, karşısındaki kişiyle duygusal manada temas kurabilmeye imkân vermesi ve ona destek olabilmesi açısından önem arz etmektedir. Birey, çevresine yönelik empatik bir yaklaşım sergilediğinde yardımda bulunma, fedakârlık gösterme gibi davranış ve olumlu tutumlarında artış meydana gelmektedir. Örneğin, Acar ve Apak (2017) yaptı̆̆ çalışmada bireylerin empatik yönelimleri arttı̆̆ında başkalarına yardım etme davranışında bulunma ve özgecilik düzeylerinin arttığını saptamıştır. Empati düzeyi yüksek bireylerin yüksek özgüven sahibi, yardımsever, iletişime açık ve duygusal kişiler olduğu görülmüştür (Durak vd., 2016:357). Birey, karşısındaki kişi ile ortak bir yaşantıda bulunup benzer hisleri deneyimlemiş ise onu duygusal olarak idrak etme noktasında daha empatik davranışlar sergiler (Stotland ve ark., 1971).

Bütün bu literatür ışığında, bilinçli farkındalık ve psikolojik sağlamlık arasındaki ilişkide temel empati becerilerinin aracı rol etkisini incelemek oldukça önemlidir. Zaten Trent, Park, Bercovitz ve Chapman (2016), empati ve bilinçli farkındalık arasındaki ilişkiyi inceleyen yeterli sayıda çalışmaların olmadığını dile getirmişlerdir. $\mathrm{Bu}$ çalışma ile bu alandaki çalışmalara katkı sunulması düşünülmektedir. Aynı şekilde bu çalışmanın psikolojik sağlamlığın dayandığı temel kavramları açıklama noktasında yol gösterici bir etkisi olacaktır. Araştırmanın asıl amacını aracı rol etkisi oluşturmaktadır. Bu yüzden de aşağıdaki soru çalışmanın amacını meydana getirmektedir.

- Bilinçli farkındalık ile psikolojik sağlamlık arasındaki ilişkide temel empati becerilerinin aracı rol etkisi var midır?

\section{Araştırmanın Amacı}

$\mathrm{Bu}$ araştırmanın amacı üniversite öğrencilerinde bilinçli farkındalık ve psikolojik sağlamlık arasındaki ilişkide bilişsel empati ve duygusal empati değişkenlerinin aracı rolünün Yapısal Eşitlik Modeli çerçevesinde incelenmesidir.

\section{YÖNTEM}

$\mathrm{Bu}$ başlık altında çalışmaya ilişkin araştırma modeli, evren-örneklem, veri toplama araçları ve veri analizi gibi çeşitli bilgiler sunulmaktadır. Araştırma kapsamında veri toplanması için Marmara Ünivesitesi'nin çeşitli fakültelerinden gerekli izinler alınmış ve ders sorumlusu gözetiminde uygulamalar katılımcı onayı alınarak yapılmıştır. 


\section{Araștırma Modeli}

$\mathrm{Bu}$ araştırma çeşitli değişkenlerin birbirleriyle olan ilişkilerini incelemek ve bu değişkenler arasındaki doğrudan ve dolaylı etkileri test etmek amacı üzerine kurgulanmış ilişkisel bir modeldir. Bu hedefe ulaşmak için de YEM ( Yapısal Eşitlik Modeli ) kullanılmıştır. Aşağıdaki hipotetik model çalışmamızın asıl amacını oluşturmaktadır.

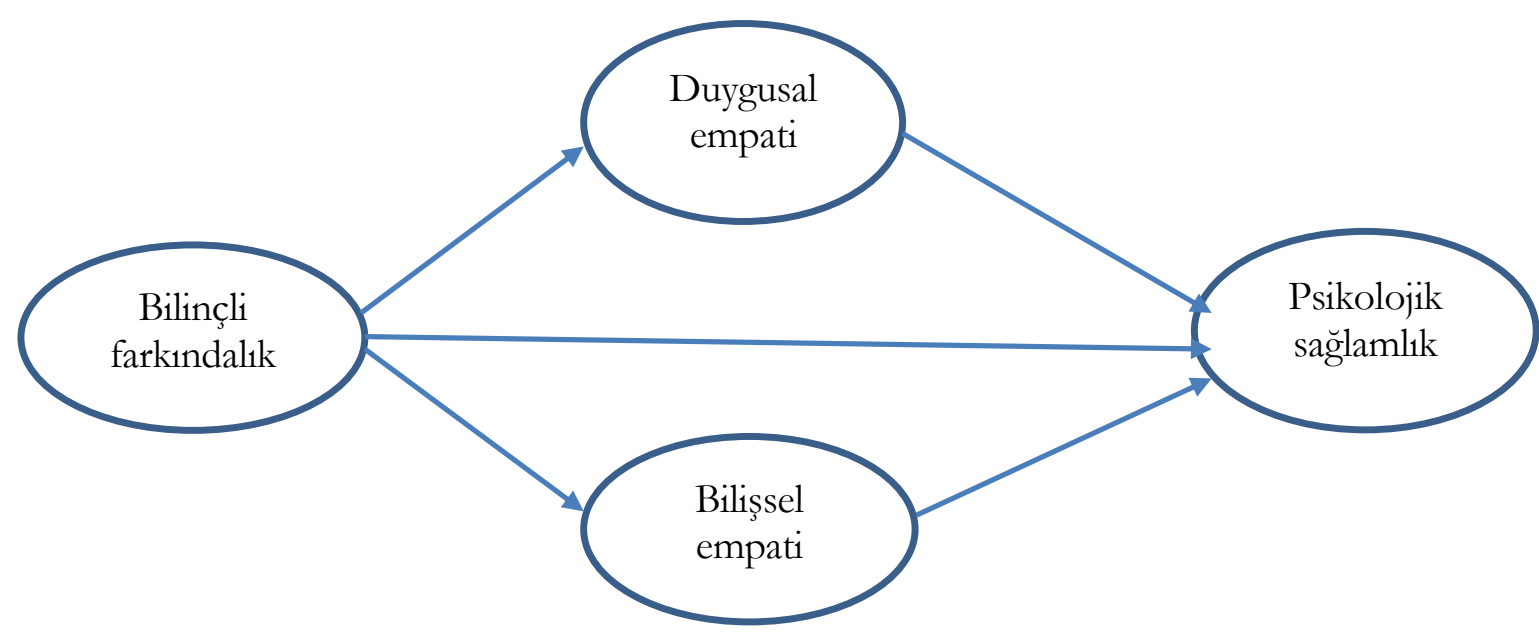

Şekil 2. Çalışmaya İlişkin Hipotetik Model

\section{Evren ve Örneklem}

$\mathrm{Bu}$ araştırmada genel evrene ulaşmanın güç olması sebebiyle çalışma evreni kullanılmıştır. $\mathrm{Bu}$ doğrultuda araştırmanın çalışma evreni, 2018-2019 öğretim yılı bahar döneminde Marmara Üniversitesine bağlı çeşitli fakültelerde lisans programlarına devam eden 77134 öğrenciden oluşmaktadır. Araştırmanın örneklem büyüklüğ̈̈ belirlenirken homojen bir yapıda olmayan evren için \% 95 güven aralığında, $\pm \% 5$ örnekleme hatası ile gerekli örneklem büyüklüğü $n=400$ olarak hesaplanmıştır (Salant ve Dillman, 1994). Örneklemin temsil oranını arttırabilmek için olası veri kayıpları da dikkate alınarak yeterli örneklem sayısı 400 kişi olarak belirlenmiştir. Araştırmanın örneklem grubu, çalışma evrenini oluşturan bölümlerden oranlı küme örnekleme yöntemi ile seçkisiz olarak seçilen çeşitli fakültelerin lisans programlarında öğrenim gören öğrencilerinden oluşmaktadır. Araştırmaya katılım için öğrencilerden onay alınmıştır. 400 kişinin katıldığ çalışmada, ölçekleri eksik dolduranlar elendiğinde, toplamda $229(\% 63,6)$ kadın ve $131(\% 36,4)$ erkek olmak üzere toplam 360 kişi katılmıştır. Katılımcıların 114'ü (\%31.7) 20 ve altı yaş, 246'sı (\%68.3) ise 21 ve üstü yaştadır. Katılımcılardan 128'i (\%35,6) Atatürk Eğitim Fakültesi, 46's1 (\%12,8) Fen Edebiyat Fakültesi, 52'si $(\% 14,4)$ İlahiyat Fakültesi, 46's1 $(12,8)$ Teknoloji Fakültesi, 50'si $(\% 13,9)$ Mühendislik Fakültesi ve 38'i $(\% 10,6)$ Sağlık Bilimleri Fakültesi öğrencisidir. Katılımcıların sınıf düzeylerine bakıldığında 100 $(\% 27,8)$ kişinin 1. Sinıf öğrencisi olduğu, $73(\% 20,3)$ kişinin 2. Sinıf öğrencisi olduğu, $101(\% 28,1)$ kişinin 3. Sınıf öğrencisi olduğu ve $86(\% 23,9)$ kişinin ise 4. Sınıf öğrencisi olduğu görülmektedir.

\section{Sinırlılıklar}

$\mathrm{Bu}$ araştırma Marmara Üniversitesi’nin değişik fakültelerinde eğitim gören öğrencilerin, araştırma kapsamında kullanılan ölçme araçlarına verdikleri cevaplarla sınırlıdır. Araştırma kapsamında elde edilen veriler bu cevaplar dikkate alınarak işleme alınmıştır.

\section{Veri Toplama Araçları}

Temel Empati Ölçeği: Temel Empati Ölçeği Jolliffe ve Farrington (2006) tarafindan dört temel duygu (korku, üzüntü, öfke, mutluluk) çerçevesinde empati seviyesini ölçmek için geliştirilmiştir. Topçu, Ç., Baker, Ö. E., ve Aydın, Y. Ç. (2010) tarafından Temel Empati Ölçeğinden Türkçeye uyarlanmıştır. Ölçek 20 maddeden oluşup 11 maddesi duygusal empatiyi 9 maddesi ise bilişsel empatiyi ölçmektedir. 
Negatif puanl 18 madde (reversed items) ters çevrilerek tekrar puanlanır. Bilişsel empati alt boyutu için ölçekten alınabilecek en düşük puan 9, en yüksek puan $45^{\prime}$ tir. Duygusal empati alt boyutu için ise ölçekten alınabilecek en düşük puan 11, en yüksek puan 55'tir. Ölçek 5'li likert tipindedir. Ölçeğe ilişkin maddeler 'Kesinlikle Katılmıyorum' ve 'Kesinlikle Katılıyorum' arasında puanlanmaktadır. Ölçeğin iç tutarlılık katsayı duygusal boyut için .74 ve bilişsel boyut için .79'dur.

Bilinçli Farkındalık Ölçeği (BİFÖ): Brown ve Ryan (2003) tarafından geliştirilen Bilinçli Farkındalık Ölçeği (BİFÖ), günlük yaşamdaki anlık deneyimlerin farkında ve bunlara karşı dikkatli olma yönündeki genel eğilimi ölçen 15 maddelik bir ölçektir. Özyeşil ve ark., (2011) tarafından Türkçeye uyarlanmıştır. BIFÖ 6 dereceli (Hemen hemen her zaman, çoğu zaman, bazen, nadiren, oldukça seyrek, hemen hemen hiçbir zaman) Likert tipi bir ölçektir. BİFÖ' nün faktör yapısını belirlemek amacıyla uygulanan açımlayıcı ve doğrulayıcı faktör analizleri sonuçlarına göre ölçek tek boyutlu bir yapı göstermektedir. BİFÖ için yapılan madde toplam korelasyonu sonucunda ölçeğin bütün maddeleri için .40'ın üzerinde ilişki ortaya çıkmıştır. BİFÖ'nün her bir madde için madde faktör yükleri .48 ile .81 arasında değişmektedir. Ölçeğin Cronbach's Alpha iç tutarlılık katsayısı .80 ve test-tekrar test korelasyon .86 olarak hesaplanmıştır.

Psikolojik Sağlamlık Ölçeği: Kısa Psikolojik Sağlamlık Ölçeği (KPSÖ), bireylerin psikolojik sağlamlık düzeylerini ölçmek üzere amacıyla Smith ve ark. (2008) tarafından geliştirilmiştir. Doğan (2015) tarafindan Türkçeye uyarlanmıştır. KPSÖ, 6 maddelik, 5'li Likert tarzında bir ölçektir. "Hiç uygun değil" (1), "Uygun Değil" (2), "Biraz Uygun" (3), "Uygun" (4), "Tamamen Uygun" (5) şeklinde bir cevaplama anahtarına sahiptir. Ölçekte 2, 4 ve 6. maddeler tersten kodlanmaktadır. Ölçekte bulunan ve tersten kodlanan maddeler çevrildikten sonra alınan yüksek puanlar, yüksek psikolojik sağlamlığa işaret etmektedir. KPSÖ'nün iç tutarlık güvenirlik katsayısı .80 ile .91 arasında değişen değerlerde bulunmuştur. Test tekrar test güvenirlik katsayısı ise, .62 ile .69 arasında bulunmuştur.

\section{Verilerin Analizi}

$\mathrm{Bu}$ çalışmada Marmara Üniversitesinin çeşitli fakültelerinin lisans programlarında öğrenim gören ögrencilerin bilinçli farkındalık ve psikolojik sağlamlık arasındaki iliş̧ide bilişsel empati ve duygusal empati değişkenlerinin aracı rolünün incelenmesi amaçlanmıştır. Ölçek sahiplerinden gerekli izinler alındıktan sonra veriler toplanmıştır. Verilerin çözümlenmesinde öncelikle SPPS 22 paket programı yardımıyla Pearson Çarpım Moment Korelasyon analizi, daha sonrasında yapısal eşitlik modelini test etmek için AMOS 20 paket programı kullanılmıştır. Yol analizi, değişkenlere ilişkin öngörülen nedensel ve tek yönlü ilişki dizilerini test etmeye olanak sağlayan istatistiksel teknikler topluluğudur (Tabachnick ve Fidell, 2015). Bu kapsamda çalışmanın asıl amacını oluşturan aracı rol etkisini incelemek için Yapısal Eşitlik Modeli (YEM) kullanılmış ve çalışmaya nihai hali verilmiştir. Analiz sonuçları bulgular kısmında sunulmuştur.

\section{BULGULAR}

Araştırmanın temel hipotezini oluşturan asıl analizlere geçmeden önce, çalışmanın güvenirliği açısından ön koşul analizler yapılmıştır. Bu bağlamda araştırmada yer alan katılımcıların kullanılan ölçeklerden elde ettikleri puanların ortalaması, standart sapma ve Cronbac's Alpha değerleri Tablo 1'de gösterilmektedir. Tablo 1'de görüldüğü gibi araştırmada kullanılan ölçeklerin güvenirlikleri Cronbach's Alpha değerleri incelendiğinde, elde edilen sonuçlar ölçek ve alt boyutlarının yeterli güvenirlik değerlerine sahip olduğunu göstermektedir. 
Tablo 1. Örneklemin Ölçeklerden Almış Olduğu Puanların Ortalama, Standart Sapma ve Cronbach's Alpha Değerleri

\begin{tabular}{|c|c|c|c|c|}
\hline Değişkenler & $\mathbf{N}$ & Ort. & $\mathbf{S}$ & $\begin{array}{c}\text { Cronbach's } \\
\text { Alpha }\end{array}$ \\
\hline Bilinçli Farkındalık & 360 & 64,71 & 9,45 &, 842 \\
\hline Bilişsel Empati & 360 & 35,94 & 4,84 &, 784 \\
\hline Duygusal Empati & 360 & 40,09 & 6,96 & ,796 \\
\hline Psikolojik Sağlamlık & 360 & 18,27 & 5,10 & 832 \\
\hline
\end{tabular}

Araştırma kapsamında yer alan değişkenler arası ilişkilerin şiddetini ve yönünü belirlemek amacıyla Pearson Momentler Çarpımı Korelasyon Analizi yapılmış ve analiz sonuçları Tablo 2'de sunulmuştur. Çalışmanın asıl amacı olan aracı değişkenlerin test edilebilmesi için çeşitli koşulların sağlanmış olması gerekmektedir. Bu koşullar genellikle şu basamaklardan meydana gelmektedir ( Baron, \& Kenny, 1986; Shrout, \& Bolger, 2002; Tingley, Yamamoto, Hirose, Keele, \& Imai, 2014):

- Bağımlı ve bağımsız değişkenler arasındaki ilişki anlamlı olmalıdır.

- Bağımsız değişken ile aracı değişken arasındaki ilişki anlamlı olmalıdır.

- Aracı değişken, bağımlı ve bağımsız değişken arasındaki ilişkiyi ya tamamen ya da kısmen azaltmalıdır.

Önkoşullar dikkate alınarak Tablo 2'deki korelasyon değerleri yorumlanmıştır.

Tablo 2. Araştırmanın Değişkenlerine Ait Korelasyon Katsayısı Değerleri

\begin{tabular}{lcccc}
\hline Değişkenler & 1 & 2 & 3 & 4 \\
\hline Bilinçli Farkındalık & 1 &, $205^{* *}$ &,$- 093^{*}$ &, $293^{* *}$ \\
Bilişsel Empati & & 1 &, $392^{* *}$ &, $117^{*}$ \\
Duygusal Empati & & & 1 &,$- 289^{* *}$ \\
Psikolojik Sağlamlık & & & & 1 \\
\hline
\end{tabular}

\footnotetext{
$* \mathrm{p}<, 05$ düzeyinde anlaml1

** $\mathrm{p}<, 001$ düzeyinde anlamlı
}

Çalışmanın asıl amacı olan, bilinçli farkındalık ile psikolojik sağlamlık arasındaki ilişkide temel empatinin (bilişsel ve duygusal empati) aracı rolü analizlerini gerçekleştirebilmek için korelasyon değerlerinin uygun olması gerekmektedir. Bilinçli farkındalık ve psikolojik sağlamlık arasındaki ilişki incelendiğinde, aradaki ilişkinin $(\mathrm{r}=, 293 ; \mathrm{p}<, 001)$ düzeyinde anlamlı olduğu görülmektedir. Arac1 değişken olarak düşünülen bilişsel empati ve duygusal empati değişkenlerinin psikolojik sağlamlıkla anlamlı bir ilişki içinde olduğu analizler neticesinde görülmüştür $\left(r_{1}=, 205 ; p<001 ; r_{2}=-, 093 ; p<, 05\right)$. Dolayısıyla bundan sonraki süreçte modele bilişsel ve duygusal empatinin aracı rol etkisi dâhil edilerek devam edilecektir. Bu analizlere ilişkin bulgular Model 1 ve Model 2'de sunulmuştur. 
Model 1. Bilinçli Farkındalık ve Psikolojik Sağlamlık Arasındaki İlişkiye İlişkin Model (**p<.01).

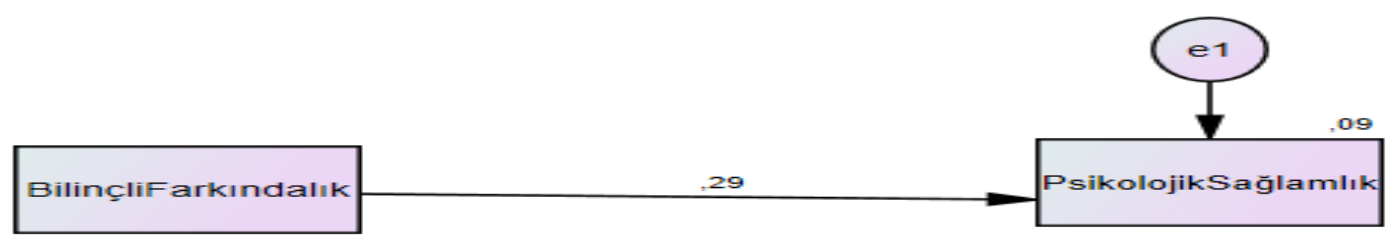

Model 1 incelendiğinde bilinçli farkındalık ve psikolojik sağlamlık arasındaki ilişkinin $(\mathrm{r}=, 29$; $\mathrm{p}<, 001)$ düzeyinde anlamlı olduğu görülmüsstür.

Model 2. Bilinçli Farkındalık ve Psikolojik Sağlamlık Arasındaki İlişkide Bilişsel ve Duygusal Empati Değiş̧kenlerinin Kısmi Aracı Rol Etkisine Illişkin Model ( $p<, 05)$.

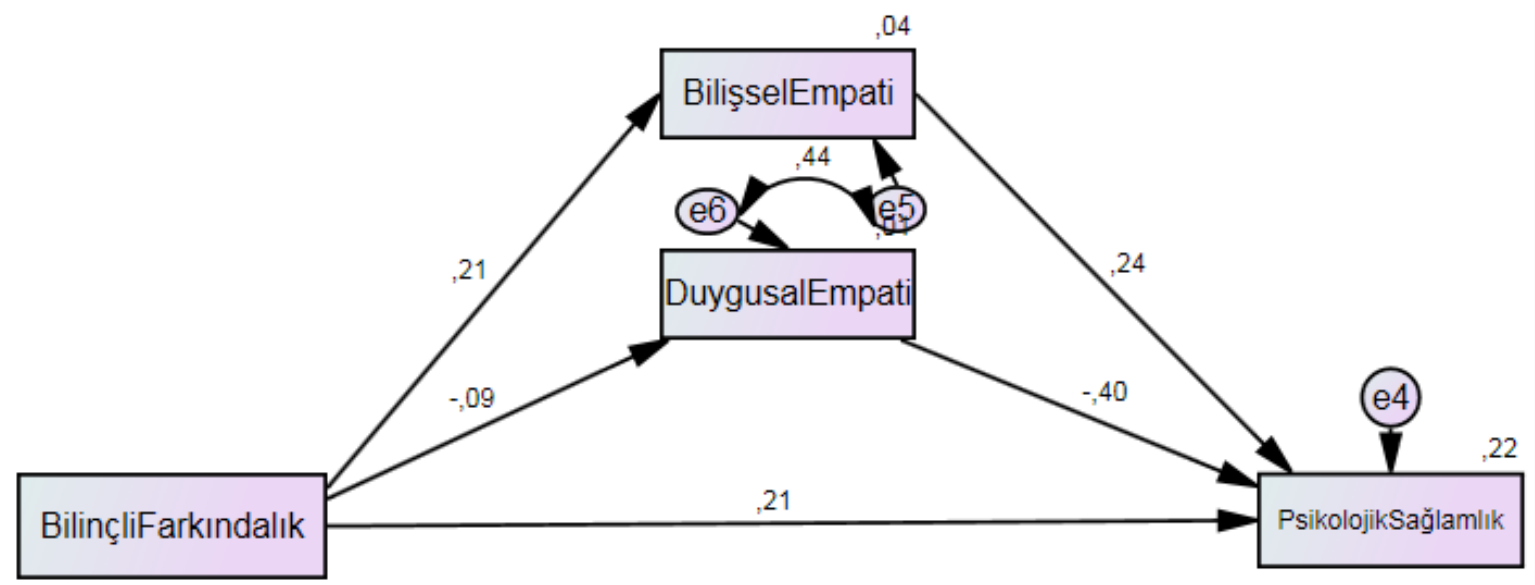

${ }^{*} \mathrm{p}<, 01$; Bilinçli farkındalık ve duygusal empati

**p<,001; Bilinçli Farkındalık ile Bilişsel Empati; Bilinçli Farkındalık ile Psikolojik Sağlamlık; Bilişsel Empati ile Psikolojik Sağlamlık

Model 2'de bilinçli farkındalık ve psikolojik sağlamlık arasındaki ilişkide bilişsel ve duygusal empati değişkenlerinin aracı rol etkisine bakıldığında, her iki değişkenin kısmi aracı rol etkisine sahip oldukları görülmektedir. Zira daha önce $(r=, 29)$ iken değişkenlerin aracı rol etkisiyle bu ilişki $(r=, 21)$ düzeyine gerilemiştir. Bu durumda bilişsel ve duygusal empati değişkenlerinin, bilinçli farkındalık ve psikolojik sağlamlık arasında kısmi aracı rol etkisine sahip oldukları görülmektedir. Çalışmaya ilişkin model iyiliği değerleri Tablo 3'te verilmiştir.

Tablo 3. Modele İlişkin Uyum İyiliği Değerleri

$\begin{array}{lc}\text { İndeksler } & \begin{array}{c}\text { İyilik } \\ \text { Değerleri }\end{array}\end{array}$

\begin{tabular}{lcc}
\hline$\chi^{2} / \mathbf{s d}$ &, 000 & $\leq 5$ Kabul edilebilir uyum, $\leq 3$ mükemmel uyum (büyük \\
örneklemlerde)
\end{tabular}


GFI

1.000

AGFI

1.000

CFI

1.000

IFI

TLI (NNFI)
$.85-.89$ arası kabul edilebilir uyum, $\geq .90$ iyi uyum

$.85-.89$ arası kabul edilebilir uyum, $\geq .90$ iyi uyum

$\geq .90$ kabul edilebilir uyum, $\geq .95$ iyi uyum, $\geq .97$ mükemmel uyum

$\geq .90$ kabul edilebilir uyum, $\geq .95$ iyi uyum, $\geq .97$

mükemmel uyum

$\geq .90$ kabul edilebilir uyum, $\geq .95$ iyi uyum

(Munro, 2005; Schreiber, Nora, Stage, Barlow and King, 2006; Schumacker and Lomax, 2010; Waltz, Strcikland and Lenz 2010; Wang and Wang, 2012).

Modele ilişkin uyum indeksleri tablodan anlaşıldığı üzere iyi uyum göstermektedir.

Tablo 4. Modele Ait Bootstrapping İşlemi

\begin{tabular}{|c|c|c|c|c|c|}
\hline \multicolumn{4}{|c|}{ Model Yolları } & \multicolumn{2}{|c|}{ \%95 BCa Güven Aralığı } \\
\hline \multicolumn{3}{|c|}{ Model 2} & Katsayı & Düşük & Yüksek \\
\hline \multicolumn{6}{|c|}{ Doğrudan } \\
\hline $\mathrm{BE}$ & PS & & ,237 & ,141 & ,314 \\
\hline $\mathrm{DE}$ & PS & &,- 400 &,- 478 &,- 318 \\
\hline $\mathrm{BF}$ & PS & & ,213 & ,133 & 293 \\
\hline \multicolumn{6}{|c|}{ Dolaylı } \\
\hline $\mathrm{BF}$ & BE-DE & PS & 052 & 011 & , 148 \\
\hline
\end{tabular}

Not: $B E$ Bilişsel Empati; $D E$ Duygusal empati; $B F$ Bilişsel Farkındalık; $P S$ Psikolojik Sağlamlık

Bootstrapping işlemi sonuçlarının gösterildiği Tablo 4 incelendiğinde, modelde hem doğrudan hem de dolaylı ölçülen katsayıların toplam değerlerinin anlamlı olduğu görülmektedir (bootstrap katsayısı model $=.052,95 \%$ G.A. $=.011, .148$ ). Elde edilen bu sonuçlar bilişsel empati ve duygusal empati değişkenlerinin üniversite öğrencilerinin bilinçli farkındalık ve psikolojik sağlamlık arasında kısmi aracı rol işlevi görmektedir.

\section{SONUÇLAR ve TARTIŞMA}

Bu başlık altında, araştırma kapsamında elde edilen bulgular ele alınmış ve yorumlamalar yapılmıştır. Araştırmada ilk önce kullanılan ölçeklerin güvenirlik değerlerine bakılmış ve üç ölçek için de Cronbach's alpha iç tutarlılık katsayılarının kabul edilebilir (Büyüköztürk, 2015) değerleri $(, 70)$ karşıladığı görülmektedir. Bu iç tutarlılık bilinçli farkındalık için $(\alpha=, 842)$; bilişsel empati için $(\alpha=, 784)$; duygusal empati için $(\alpha=, 796)$ ve psikolojik sağlamlık için $(\alpha=, 832)$ olarak elde edilmiştir. Bu neticeler çalışmada kullanılan ölçeklerin güvenilirliği için önemli değerler olarak kabul edilmektedir. Çalışmanın asıl amacı olan bilinçli farkındalık ve psikolojik sağlamlık arasındaki ilişkide bilişsel ve duygusal empati değişkenlerinin aracı rol etkisinin incelenmesi için yapılan analizler neticesinde, ilk önce bilinçli farkındalık ve psikolojik sağlamlık arasındaki ilişkiye bakılmış ve her iki değişken arasında pozitif yönlü anlamlı bir ilişki bulunmuştur ( $\mathrm{r}=, 29 ; \mathrm{p}<, 001)$.

Literatür incelendiğinde bilinçli farkındalık ve psikolojik sağlamlık, dayanıklılık ya da iyi oluş arasındaki ilişkiyi inceleyen çok sayıda çalışmanın olduğu görülmektedir. Bilinçli farkındalık ve psikolojik iyi oluş arasındaki ilişkinin incelendiği bir çalışmada, bilinçli farkındalık ve psikolojik iyi oluş arasında pozitif 
yönlü ve anlamlı bir ilişki bulunmuştur (Brown ve Ryan, 2003). Benzer bir çalışmayı üniversite öğrencileriyle yapan Weinstein, Brown ve Ryan (2009) yaptıkları çalışmada bilinçli farkındalığın stresle başa çıkmada olumlu etkisinin olduğu, aynı şekilde bilinçli farkındalık ve psikolojik iyi oluş arasında pozitif yönlü bir ilişkinin olduğu sonucunu elde etmişlerdir. Bowlin ve Baer (2012) yaptıkları çalışmada bilinçli farkındalık ve psikolojik sağlamlık arasında pozitif yönlü bir ilişki elde etmişlerdir. Tüm bu çalışmalar bilinçli farkındalık ve psikolojik arasındaki sağlamlığın ne denli önemli olduğunu göstermektedir. Bu çalışmayı önemli kılan husus; bilinçli farkındalık ve psikolojik sağlamlık arasındaki ilişkide temel empati becerilerinin aracı rol etkisinin olup olmadığının incelenmesidir. Diğer bir ifadeyle bilinçli farkındalığın psikolojik sağlamlığı yordamasında temel empati becerilerinin bir payı var mıdır? Sorusuna cevap aranmaktadir.

Yapılan analizler neticesinde bilinçli farkındalık ve psikolojik sağlamlık arasındaki ilişkinin bir kısmının temel empati becerileri olan bilişsel empati ve duygusal empati değişkenleri tarafindan açıklandığı sonucu elde edilmiștir. Çalıșmamızda bilinçli farkındalık ile bilișsel empati arasında pozitif yönlü bir ilişki elde edilirken; bilinçli farkındalık ile duygusal empati arasında negatif yönlü bir ilişki bulunmuştur. Benzer bir sonucu Uygur (2019) yaptığı çalışmada elde etmiştir. Aynı şekilde Birnie ve arkadaşları (2010), Greasan ve Cashwell (2009), Trent ve arkadaşları (2016) yaptıkları çalışmalarda bilinçli farkındalık ile bilişsel empati arasında pozitif bir ilişki elde etmişlerdir. Çalışmamız sonucunda elde edilen bilinçli farkındalık ve duygusal empati arasındaki ilişkinin negatif olması da birçok çalışmada yer almıştır. Alan yazında duygusal empati, olumsuz duygular yaşayan kişilerin duygularının bir kısmını yüklenmek olarak ele alındığından, bu durum bilinçli farkındalık düzeyinde azalmaya sebep olabilmektedir şeklinde açıklanmıştır (Guttman ve Laporte, 2000; Germer, 2009). Aynı şekilde bilişsel empati ile psikolojik sağlamlık arasında pozitif yönlü bir ilişki varken; duygusal empati ile psikolojik sağlamlık arasında negatif bir ilişki bulunmuştur. Çalışmamız kapsamında elde edilen sonuçlar literatür ile paralellik göstermekte ve yapılmış olan çok sayıda çalışmayla benzer sonuçlar vermektedir (Bajaj ve Pande, 2015; Baysal ve Demirbaş, 2012; Deniz, Erus ve Büyükcebeci, 2017; Sarıçalı ve Satıc1, 2017).

Çalışmanın asıl amacı olan, bilinçli farkındalık ve psikolojik sağlamlık arasındaki ilişkide temel empati becerisinin aracı rol etkisi için yapılan analizler neticesinde, temel empatinin kısmi aracı rol etkisinin olduğu saptanmıştır. Bu bağlamda bilinçli farkındalık ve psikolojik sağlamlık arasındaki ilişkinin bir kısmının temel empati tarafından açıklanıp açıklanmadığı için denenen hipotez doğrulanmış bulunmaktadır. Bu durumu daha açık bir şekilde ifade etmek gerekirse; bilinçli farkındalığın psikolojik sağlamlığı yordamasında temel empati becerilerinin anlamlı düzeyde etkisi söz konusudur. Yapısal model ve bootstraping sonuçları incelendiğinde özellikle bilişsel empatinin daha yüksek düzeyde aracı etki gösterdiği görülmektedir. Aynı zamanda bilişsel empatinin pozitif yönlü duygusal empatinin ise negatif etkisi olduğu yine araştırma kapsamında ulaşılan sonuçlardandır. Çok sayıda çalışmada benzer bir ilişki elde edilmiştir (Uygur, 2019; Birnie vd.; Greasan and Cashwell 2009).

Araştırma kapsamında elde edilen sonuçlar bağlamında, araştırmacı ve araştırıcılara çeşitli öneriler sunulmaktadır;

- Bilinçli farkındalık eğitimleri düzenlenerek, öğrencilerin psikolojik sağlamlıklarına katkıda bulunulabilir.

- Aynı şekilde bilişsel empati becerilerinin geliştirilmesi de Psikolojik sağlamlığa katkıda bulunulabilir.

- Duygusal empatinin gerek bilinçli farkındalık ve gerekse psikolojik sağlamlıkla olan ilişkisi negatif çıktığından, öğrencilerin daha çok bilişsel empati becerileri kazanmaları desteklenmelidir.

- Bilinçli farkındalık ve Psikolojik sağlamlık arasında aracı rol ilişkisi olabilecek diğer değişkenlerle de çalışılabilir.

- $\mathrm{Bu}$ değikenlerle ilgili yapılacak psiko eğitimlerin, öğrencilerin bu konulardaki farkındalık düzeylerini artıracağı düşünülmektedir. 
- Alan yazına önemli katkılar sağlayacağı düşünülen çalışmamıza benzer çalışmaların yapılması, literature önemli katkılar sağlayacaktır.

- Çalışma üniversite öğrencileriyle sınırlı olduğundan, daha farklı evren ve örneklemler ile yapılacak çalışmalar alanyazına katkı sağlayacaktır.

Bilgilendirme / Acknowledgement:

1- Bu çalışmada tüm yazarların katkıları bulunmaktadır.

2- Bu makalenin ilk hali 3. Avrasya Pozitif Psikoloji Kongresi'nde sunulmuştur.

3- Makalenin yazarları arasında çıkar çatışması bulunmamaktadır.

4- Bu makaledeki veriler 2019 yılında toplanıp yorumlanmıştır. Uygulama sırasında tüm fakültelerden ve ders sorumlularından gerekli izinler alınmıştır.

5- Bu makalede araştırma ve yayın etiğine uyulmuştur.

\section{KAYNAKÇA}

Acar, M. C., \& Apak, H. (2017). Sosyal hizmet bölümü öğrencilerinin empatik eğilimleri ile özgecilik düzeyleri arasındaki ilişkinin incelenmesi. Toplum ve Sosyal Hizmet, 28(1), 93-112.

Akduman, G., Karahan, G., \& Solmaz, M. S. (2018). İletişim becerileri üstünde empati ve psikolojik sağlamlığın etkisi. Finans Ekonomi ve Sosyal Araştırmalar Dergisi (FESA), 3(4), 765-775.

Akın, Ü., Akın, A., \& Abacı, R. (2007). Öz-duyarlık ölçeği: geçerlik ve güvenirlik çalışması selfcompassion scale: the study of validity and rehability. Hacettepe University Journal of Education, 33, 01-1.

Arslan, I. (2018). Bilinçli farkindalik, depresyon düzeyleri ve algilanan stres arasindaki ilişki. Birey ve Toplum Sosyal Bilimler Dergisi, 8(2), 73-86.

Ataşalar, J. (1996). Üniversite ögrrencilerinin empatik eğilim düzeylerine cinsiyet ve yaşlarına göre kendini açma davranışları. Yayımlanmamış yüksek lisans tezi, Hacettepe Üniversitesi, Ankara.

Bajaj, B. ve Pande, N. (2015). Mediating role of resilience in the impact of mindfulness on life satisfaction and affect as indices of subjective wellbeing. Personality and Individual Differences, 93, 63-67.

Baron, R. M., \& Kenny, D. A. (1986). The moderator-mediator variable distinction in social psychological research: Conceptual, strategic, and statistical considerations. Journal of Personality and Social Psychology, 5, 1173-1182.

Barret-Lennard, G. T. (1981). The empathy cycle: Refinement of a nuclear concept. Journal of Counseling Psychology, 28(2), 91-100.

Baş, A. U., \& Yurdabakan, İ. (2017). Psikolojik sağlamlık ve okul ikliminin ortaokul öğrencilerinin yaşam doyumunu yordama gücü. Mehmet Akif Ersoy Üniversitesi Eğitim Fakültesi Dergisi, $1(41), 202-214$.

Baysal, N. ve Demirbaş, B. (2012). Sınıf öğretmenliği adaylarının bilinçli farkındalıkları ile yansıtıcı düşünme eğilimleri arasındaki ilişsinin incelenmesi. Ĕgitim ve Ögretim Araştırmaları Dergisi, $1(4), 12-20$.

Birnie, K., Speca, M. ve Carlson, L.E. (2010). Exploring self-compassion and empathy in the context of mindfulness-based stress reduction (MBSR). Stress and Health, 26(5), 359-371.

Bora, E., \& Baysan, L. (2009). Empati ölçeği-Türkçe formunun üniversite öğrencilerinde psikometrik özellikleri. Klinik Psikofarmakoloji Bulteni, 19(1), 39-47. 
Bowlin, S. L., ve Baer, R. A. (2012). Relationships between mindfulness, self-control, and psychological functioning. Personality and Individual Differences, 52(3), 411-5.

Brooks, R. B. ve Goldstein, S. (2003). Power of resilience. US: McGraw-Hill Companies.

Brown K.W. ve Ryan, R. M. (2003). The benefits of being present, mindfulness and its role in psychological well-being. Journal of Personality and Social Psychology, 84(4), 822-848.

Brown, K. M., Ryan, R. M. ve Creswell, C. D. (2007). Mindfulness: Theoretical foundations and evidence for its salutary effects. Psychological Inquiry, 18(4), 211-237.

Bryant, D. ve Clark, P. (2006). Historial empathy and Canada: A people's history. Canadian Journal of Education, 29(4), 1039-1064.

Büyüköztürk, Ş. (2015). Sosyal bilimler için veri analizi el kitabı: İstatistik, araştırma deseni. SPSS uygulamaları ve yorum. (Gözden geçirilmiş yirmi birinci baskı). Ankara: Pegem Yayıncılık.

Çelikler, A. N. (2017). Bir grup genç yetişkinde bilinçli farkindalik düzeyi ile başa çikma tutumlari ve psikolojik iyi oluş arasindaki ilişkinin incelenmesi. Yayımlanmamış yüksek lisans tezi, Haliç Üniversitesi, İstanbul.

Davis, M. H. (1980). A multidimensional approach to individual differences in empathy. JSAS Catalog of Selected Documents in Psychology, 10, 85.

Deniz, M. E., Erus, S. M. ve Büyükcebeci, A. (2017). Bilinçli farkındalık ile psikolojik iyi oluş ilişkisinde duygusal zekanın aracılık rolü. Türk Psikolojik Danışma ve Rehberlik Dergisi, 7(47), 17-31.

Deniz, M. E., Şahin, S. ve Sümer, A. S. (2008). The validity and reliability of the turkish version of the self-compassion scale. Social Behavior and Personality, 36(9), 1151 - 1160.

Doğan, T. (2015). Kısa psikolojik sağlamlık ölçeği'nin türkçe uyarlaması: geçerlik ve güvenirlik çalışması. The Journal of Happiness \& Well-Being, 3(1), 93-102.

Dökmen, Ü. (2005). Sanatta ve günlük yasamda iletişim çatışmaları ve empati. İstanbul: Sistem Yayınc1lik

Durak, M., Durak-Şenol, E., Kocatepe, U. (2016). Aklımın akll: psikoloji. ikinci basımdan çeviri. Ankara: Nobel Akademik Yayıncılık.

Ezer, H.İ. (2017). Ergenlik döneminde yaygın kullanılan savunma mekanizmaları ile psikolojik sağlamlık ve mutluluk düzeyi arasındaki ilişki: Hatay il merkezi örneği. Yayınlanmamış doktora tezi, Çağ Üniversitesi, Mersin.

Garmezy, N. (1991). Resiliency and vulnerability to adverse developmental outcomes associated with poverty. American Behavioral Scientist, 34, 416430

Garmezy, N., Masten, A. S., \& Tellegen, A. (1984). The study of stress and competence in children: A building block for developmental psychopathology. Child Development, 55, 97-111.

Germer, C. K. (2009). The mindful path to self-compassion: Freeing yourself from destructive thoughts and emotions. New York:Guilford Press.

Germer, C. K., Siegel, R. D., \& Fulton, P. R. (2005). Mindfulness and psychotherapy. New York: Guilford Press.

Greason, P.B. ve Cashwell, C.S. (2009). Mindfulness and counseling self-efficacy: The mediating role of attention and empathy. Counselor Education \& Supervision, 49(1), 2-19.

Greco, L. A., Baer, R. A., \& Smith, G. T. (2011). Assessing mindfulness in children and adolescents: Development and validation of the child and adolescent mindfulness measure (CAMM). Psychological assessment, 23(3), 606. 
Guttman, H.A. ve LaPorte, L. (2000). Empathy in families of women with borderline personality disorder, anorexia nervosa, and a control group. Family Process, 39(3), 345-358.

Haynes, N. M. (2005). Personalized leadership for effective schooling. 23 Temmuz 2017 tarihinde http://www.atdp.berkeley.edu/haynes_keynote_04.ppt adresinden erişildi.

Hoffman, M. L. (1984). Interaction of affect and cognition in empathy. 23 Temmuz 2019 tarihinde https://books.google.com.tr/books?hl=tr\&lr=\&id=IpY5AAAAIAAJ\&oi=fnd\&pg=PA103\&dq=H offman,+M.+L.+(1984).+Interaction+of+affect+and+cognition+in+empathy.+In+C.+E.+Izard,+J \&ots $=\mathrm{G} 23 \mathrm{sf} 2 \mathrm{AyfG} \& \mathrm{sig}=\mathrm{xv} 26 \mathrm{AOyQWABO} 8 \mathrm{U} 01 \mathrm{fwHZvs} 8 \mathrm{FRoU} \&$ redir_esc $=\mathrm{y} \# \mathrm{v}=$ onepage\&q \& $\mathrm{f}=$ false adresinden erişildi.

Hoffman, M. L. (1987). The contribution of empathy to justice and moral judgment. 20 Temmuz 2019 tarihinde https://books.google.com.tr/books?hl=tr\&lr=\&id=PVQ4AAAAIAAJ\&oi=fnd\&pg=PA47\&dq=H offman,+M.+L.+(1987).+The+contribution+of+empathy+to+justice+and+moral+judgment.+In+ N.\&ots=Km5M5vkozy\&sig=lTm2HlZ8KwYlwrhsHa7QSn7ajk\&redir_esc $=\mathrm{y} \# \mathrm{v}=$ onepage \&q=Hoffman\%2C\%20M.\%20L.\%20(1987).\%20The\%20contribution $\% 20$ of $\% 20$ empathy $\% 20$ to $\% 20$ justice $\% 20$ and $\% 20$ moral $\% 20$ judgment. $\% 20 \mathrm{In} \% 20 \mathrm{~N} . \& \mathrm{f}=$ false adresinden erişildi.

Hogan, R. (1969). Development of an empathy scale. Journal of Consulting and Clinical Psychology, 33(3), 307-316.

Jolliffe, D. ve Farrington, D. P. (2006). Development and validation of the Basic Empathy. Journal of Adolescence, 29(4),589-611.

Kabat-Zinn, J. (1990). Full catastrophe living: using the wisdom of your mind to face stress, pain and ilness. New York: Dell Publishing.

Kabat-Zinn, J. (1994). Wherever you go, there you are: Mindfulness meditation in everyday life. New York: Hyperion.

Karataş, Z. (2012). Eğitim fakültesi öğrencilerinin empatik becerileri ve benlik saygısı düzeylerinin incelenmesi. Mehmet Akif Ersoy Üniversitesi Eğitim Fakültesi Dergisi, 1(23), 97-114.

Kiraz, C. (2011). Ĕ̆itim fakültesi öğrencilerinin empatik ĕgilimleri ile narsistik kişilik özellikleri. Yayınlanmamış Yüksek Lisans Tezi, Yeditepe Üniversitesi, İstanbul.

Luthar, S. S., \& Cicchetti, D. (2000). The construct of resilience: Implications for interventions and social policies. Development and Psychopathology, 12, 857-885

Luthar, S. S., Cicchetti, D. ve Becker, B. (2000). The construct of resilience: a critical evaluation and guidelines for future work. Child Development, 71(3), 543-562.

Masten, A., \& Gewirtz, A. (2006). Resilience in development: The importance of early childhood. (R. Tremblay, R. Barr, R. Peters, \& H. E. G. Accessed, Ed.) Encyclopedia on early childhood development (Online), 1-6. Montreal. 12 Nisan 2017 tarihinde https://www.researchgate.net/Publication/252094504_Resilience_Ġn_Development The_Importance_Of_Early_Childhood adresinden erişildi.

Masten, A.S., \& Reed, M.G. (2002). Resilience in development. C. R. Snyder \& S. J. Lopez (Ed.), The handbook of positive psychology içinde. 74-88. New York, NY: Oxford University Press.

Masten, A.S., Best, K. M., \& Garmezy, N. (1990). Resilience and development: Contributions from the study of children who overcome adversity. Development and Psychopathology, 2, 425-444.

Munro, B., H. (2005). Statistical methods for health care research. Philadelphia: Lippincott Williams \& Wilkins.

National Institute of Mental Health. (1995). Basic behavioral science research for mental health: A national investment. Washington DC: U.S. Department of Health and Human Services. 
Neff, K. D. (2003). The Development and validation of a scale to measure self compassion. Self and Identity, 2, $223-250$.

Öz, F., Bahadır-Yılmaz, E. (2009). Ruh sağlığının korunmasında önemli bir kavram: psikolojik sağlamlık. Sağllk Bilimleri Fakültesi Hemşirelik Dergisi, 16(3), 82-89.

Özyeşil, Z. (2011b). Üniversite öğrencilerinin öz-anlayış düzeylerinin bilinçli farkındalık kişilik özellikleri ve bazı değişkenler arasından incelenmesi. Yayımlanmamış doktora tezi, Selçuk Üniversitesi Eğitim Bilimleri Enstitüsü, Konya.

Özyeşil, Z., Arslan, C., Kesici, Ş., \& Deniz, M. E. (2011). Bilinçli farkındalık ölçeği’ni Türkçeye uyarlama çalışması. Eğitim ve Bilim, 36(160), 224-235.

Rogers, C. R. (1983). Empatik olmak değeri anlaşılmamış bir varoluş şeklidir. Çev. F. Akkoyun. Ankara Üniversitesi EBF Dergisi, 16, 103-124.

Salant, P., \& Dillman, D. A. (1994). How to conduct your own survey? New York: John Wiley and Sons.

Sarıçalı, M. ve Satıcı, S. A. (2017). Bilinçli farkındalık ile psikolojik kırılganlık ilişkisinde utangaçlığın arac1 rolü. Hitit Üniversitesi Sosyal Bilimler Enstitüsü Dergisi, 10(1), 655-670.

Schreiber, J., B., Nora, A., Stage, F., K., Barlow, E., A., King, J. (2006). Reporting structural equation modeling and confirmatory factor analysis results: a review. The Journal of Educational Research, 99(6), 323-338.

Schumacker, R., E., Lomax, R., G. (2010). A beginner's guide to structural equation modeling. New York: Taylor \& Francis Group.

Schützenberger-Ancelin, A. (1995). Psikodrama: yöntemlerin bir özet sunumu. Çev. A. Özbek. Ankara: Grup Psitoterapileri Derneği.

Sezgin, O., \& Sezgin, A. S. (2011). Psiko-sosyal açıdan küreselleşme, empoze kültür ve davranışa yansıması. Kalem Eğitim ve İnsan Bilimleri Dergisi, 1(1), 91-122.

Sharma, RM. (1992). Empathy: A retrospective on its development in psychotherapy. Austr NZJ Psychiatry, 26,377-390.

Shrout, P. E., \& Bolger, N. (2002). Mediation in experimental and nonexperimental studies: new procedures and recommendations. Psychological Methods, 7, 422-445.

Smith, B. W., Dalen, J., Wiggins, K., Tooley, E., Christopher, P., \& Jennifer Bernard, J. (2008). The brief resilience scale: Assessing the ability to bounce back. International Journal of Behavioral Medicine, 15, 194-200.

Staub, E. (1987). Commentary on part I. Empathy and its development, 103-115.

Stotland, E., Sherman, S. E., \& Shaver, K. G. (1971). Empathy and birth order: Some experimental explorations. US: Nebraska Press.

Thompson, K. L. ve Gullone, E. (2003). Promotion of empathy and prosocial behaviour in children through humane education. Australian Psychologist, 38, 175-182.

Tingley, D., Yamamoto, T., Hirose, K., Keele, L., \& Imai, K. (2014). Mediation: R package forcausal mediation analysi, 59(5), 1-38.

Topçu, Ç., Baker, Ö. E., \& Aydın, Y. Ç. (2010). Temel empati ölçeği Türkçe uyarlaması: geçerlik ve güvenirlik çalışması. Türk Psikolojik Danışma ve Rehberlik Dergisi, 4(34), 174-182.

Trent, N.L., Park, C., Bercovitz, K. ve Chapman, I.M. (2016). Trait socio-cognitive mindfulness is related to affective and cognitive empathy. Journal of Adult Development, 23(1), 62-67.

Tuncer, N. (2017). Bir grup üniversite ögrencisinde belirlenen sosyal anksiyete düzeylerine göre bilinçli farkindalık ve yaşam doyumu düzeylerinin incelenmesi. Yayımlanmamış yüksek lisans tezi, Işık Üniversitesi, İstanbul. 
Uygur, S., S. (2019). Ergenlerin bilinçli farkındalığının yordanmasında başa çıkma stilleri, empati ve duygusal düzenlemenin rolü. Türk Psikolojik Danışma ve Rehberlik Dergisi, 9(55), 1247-1279.

Wagnild, G. M., \& Young, H. M. (1993). Development and psychometric evaluation of the resilience scale. Journal of Nursing Measurement, 1, 165-178.

Waltz, C. F., Strcikland, O. L., Lenz, E. R., (2010). Measurement in nursing and health research. New York: Springer Publishing Company.

Wang, J., Wang, X. (2012). Structural equation modeling: applications using mplus: methods and applications. West Susex: John Wiley \& Sons.

Weinstein, N., Brown, K.W. ve Ryan, R.M. (2009). A multi-method examination of the effects of mindfulness on stress attribution, coping, and emotional wellbeing. Journal of Research in Personality, 43(3), 374-385.

Wiseman, T. (1996). A concept analysis of empathy. Journal of advanced nursing, 23(6), 1162-1167. 